How does the propensity of living near rail transit moderate the influence of rail transit on transit trip frequency in Xi'an?

Xiaoyan Huang*

Associate professor

Center for Land Resources Research in Northwest China, Institute of Transport

Geography and Spatial Planning, Shaanxi Normal University

Address: No. 620, West Chang'an Avenue, Chang'an District, Xi'an 710119, Shaanxi

Province, P.R. China

Tel: +861879288797

E-mail: hxiaoy@snnu.edu.cn

Xinyu (Jason) Cao

Associate professor

Humphrey School of Public Affairs, University of Minnesota, Twin Cities

301 19th Ave. S, Minneapolis, MN 55455, USA

E-mail:cao@umn.edu

612-625-5671

Xiaoshu Cao

professor

1.Department of Urban and Regional Planning, Sun Yat-Sen University, China

2.Center for Land Resources Research in Northwest China, Institute of Transport Geography and Spatial Planning, Shaanxi Normal University

E-mail: caoxsh@mail.sysu.edu.cn

and

Jiangbin Yin

Associate professor

Center for Land Resources Research in Northwest China, Institute of Transport

Geography and Spatial Planning, Shaanxi Normal University

E-mail: yinjb@snnu.edu.cn

*Corresponding author

\title{
Acknowledgements
}

The paper was developed from a project sponsored by the Natural Science Foundation of China (\#41401127), and supported by the National Science Foundation of USA (PIRE: 1243535) 


\section{How does the propensity of living near rail transit moderate the influence of rail transit on transit trip frequency in Xi'an?}

\section{Abstract}

Many cities have made massive investments on rail systems to substitute transit for driving. Some studies have considered the confounding effect of attitudes in the connections between rail transit and travel behavior. However, they often focused on the average effect of rail transit and assumed that individuals' responses to transit improvements do not vary by their tastes. Using the 2014 data from Xi' an in China, this study explores the interaction effect between metro transit (heavy rail) and the propensity (i.e., predicted probability) of living in neighborhoods with metro transit on transit use. The propensity is positively associated with commute by metro transit and bus. Further, individuals with a strong propensity use transit equivalently no matter whether they live near metro transit, but metro transit tends to promote transit commute for those with a weak propensity of living near metro transit. Overall, building a rail line helps enhance transit ridership. Planners should also consider the variation in responses by individuals with different tastes when using policies to shape urban travel.

Key words: residential self-selection, residential dissonance, travel behavior, transit-oriented development, propensity score, sustainability

\section{Introduction}

Rail transit systems have been considered as an effective way to mitigate urban traffic congestion, alleviate environmental impacts of transport, and stimulate economic growth by virtue of their good quality of service and capability of converting automobile users into transit users (Bhattacharjee and Goetz, 2012; Garrett and Castelazo, 2004; Knowles, 1996). Many cities worldwide have made massive investments on rail systems, especially in fast-growing developing countries. In India, urban rail is operational in nine cities, under construction in seven cities, and planned in 14 cities (Sharma et al., 2015). In mainland China, 95 rail transit lines were in operation in 22 cities by 2014 (Wang and You, 2016). Many of the cities have planned to expand and upgrade existing rail systems and some cities will build new systems. 
Many studies have explored the impacts of rail transit and/or transit-oriented development (TOD) on travel behavior. They often compare travel behavior between station area residents and the residents in the city/county/region as a whole. However, the choice of inappropriate controls tends to overstate the impact of rail transit on travel behavior (Cao and Schoner, 2014). Several studies have also disentangled the confounding effect of residential self-selection by controlling for travel attitudes and preferences. However, most of them focused on the average or independent effect of rail transit and did not consider that residents' travel responses to built environment interventions may differ among those with heterogeneous preferences (Chatman, 2014). Several studies have investigated the interaction between the built environment and attitudes to assess the moderation effect of attitudes on travel choices (Schwanen and Mokhtarian, 2004; Schwanen and Mokhtarian, 2005b). However, few have explored how residents' behavioral responses to rail transit development vary by individuals' tastes.

This study attempts to fill the gaps by exploring ridership benefits of station area residents of metro transit Line 2 in Xi'an. It accounts for the influences of the predicted probability (i.e., propensity) of living in neighborhoods with metro transit; given residents' demographics, travel attitudes, and residential preferences. This study is novel in the literature of residential dissonance and travel behavior. In particular, it innovatively adopts propensity score (Rosenbaum and Rubin, 1983) as an indicator for the propensity of living in neighborhoods with metro transit and examines the effect of its interaction with metro transit on transit use. Previous studies often used a factor score of land use or travel attitudes to measure residents' preference for a certain type of neighborhoods (Schwanen and Mokhtarian, 2004). By contrast, the propensity score integrates multiple factors that influence residential location choice, including demographics and various attitudes, and hence is better than using an attitudinal variable alone.

The remainder of this paper is organized as follows. Section 2 reviews the literature on the effects of rail transit, built environment, and residential neighborhood dissonance (or mismatch) on travel behavior. Section 3 discusses the data and method. Results are presented in Section 4. The final section summarizes the key conclusions. 


\section{Literature Review}

Many studies have examined ridership benefits of TOD and concluded that households living near rail stations have substantially higher rates of patronage on transit than those away from rail transit (Arrington and Cervero, 2008). Cervero's reports $(1993,1994)$ showed that station area residents commuted by transit around five times as many as an average resident in the same city, and that $52 \%$ of residents who drove to work prior to moving to TODs switched to transit after residing near rail transit. Using a 2003 survey of 4,785 residents living at 26 sites along California's major urban rail systems, Lund et al. (2004) found that compared to residents in the corresponding city, TOD residents tended to use transit more frequently for work (more than 5 times) and non-work (about 3.5 times) purposes. Dittmar and Ohland (2004) compiled the 2000 Census journey to work data and found that both transit and walking were more prevalent at rail station areas than in the county as a whole. Using the 2000 census data on households living in 103 TODs, Renne (2005) showed that $16.7 \%$ of TOD residents used transit for commute whereas $7.1 \%$ of residents in the 12 metropolitan regions in which the TODs were located commuted by transit.

Although these studies offer important insights regarding the impact of TOD on transit use, it is inappropriate to compare TOD to the city/county/region as a whole. Because rail transit is often planned in the key corridors that already have good bus services and high transit demand than the city/county/region as a whole (Guiliano, 2004), choosing residents in the city/county/region as control groups will overstate transport impacts of rail transit (Cao and Cao, 2014; Cao and Schoner, 2014). In a cross-sectional case-control design, it is ideal for control areas to have similar characteristics (in terms of location context, built environment elements and demographic profile) to treatment areas, except the absence of rail transit.

Furthermore, most of these studies are from North America or developed countries, and this tells only part of the story. Land use and transportation development in fast-growing developing countries has a more important effect on the environment than that in developed countries. Any environmental gains from developed countries, often costly, will be eclipsed if developing 
countries repeat the mistakes of developed countries in land use and transportation policies (Cervero, 2013). To maintain/increase transit ridership and curb the growth of traffic congestion, rail transit has recently proliferated in China. Although transit planners expect that rail transit will guide urban development and affect travel patterns, few studies have examined how it is shaping urban travel in China. Cervero and Day (2008) conducted a retrospective survey of 900 households that recently moved to 20 housing developments served by metro transit in three suburban districts in Shanghai. They found that more than $10 \%$ of household heads have switched from non-motorized transport and bus to rail transit, but few of them have given up their cars. Therefore, metro transit in suburban neighborhoods has a limited impact on the substitution for vehicular travel. Further, about $60 \%$ of household heads did not change their commute mode before and after the move. This implies that individuals choose their residential location to match their travel attitudes (Krizek, 2000). In other words, residential self-selection may be at work

Residential self-selection has been reported to confound the relationship between the built environment and travel behavior. It means that people choose where to live based on their preferences and needs for activities and associated travel. For example, individuals preferring transit may choose to live in transit-friendly neighborhoods and use transit more. In this case, the difference in transit use results from the unobserved and heterogeneous travel attitudes in determining residential location, rather than the "independent" effect of transit-friendly neighborhoods. If self-selection effect exists but is not controlled for, the relationship between TOD and travel behavior may be at least partly spurious (Bhat and Guo, 2007; Cao and Schoner, 2014). On the other hand, residential self-selection can be considered as a mechanism under which the built environment influences travel behavior (Naess, 2014). Previous studies have offered empirical evidence for residential self-selection relevant to TOD and travel behavior. Cervero (2007) found that self-selection effect was substantial in transit mode choice, accounting for approximately 40 percent of the decision to commute by rail. Cao and Schoner (2014) used a survey of 1,303 respondents in 2011 to explore the impact of the Hiawatha LRT on transit use. They applied the propensity score matching method to account for self-selection effect. They found that residents who moved to the Hiawatha light rail corridor before its opening used transit 
more frequently than residents in control corridors whereas residents moving to the Hiawatha corridor after its opening used transit similar to those in control corridors. However, they did not differentiate the impacts of rail transit itself and station area environments on travel behavior. If station environments play a key role, building a rail line is insufficient to enhance transit ridership. Well-coordinated land use and transportation policies should be in order (Houston et al., 2015). Chatman (2013) surveyed households living within two miles of 10 rail stations in Northern New Jersey and examined the impact of rail transit on auto ownership and auto use. He found that residential preferences are significantly correlated with auto commuting and the low auto use in TODs is not due to rail transit but built environment elements. In this study, the effect on auto use is the average treatment effect of built environment elements. He did not consider the possibility that residents' responses to built environment elements may differ among those with heterogeneous residential preferences (Chatman, 2014). Built environment variables and preferences may have an interaction effect; that is, the effect of one variable depends on the level of the other variable. Thus, just simply "controlling for" demographics and preferences may miss important distinctions among individuals (Adler et al., 1994; Manaugh and El-Geneidy, 2011). In other words, the effect of the built environment on travel is not "one size fits all" but varies based on individuals' preferences.

Several studies have explored the interaction between the built environment and attitudes to assess the moderation effect on travel choices. Using a survey of 1,358 commuters in three neighborhoods in the San Francisco Bay Area, Schwanen and Mokhtarian (2004) measured residential dissonance (or mismatch) between actual and preferred residential location. They distinguished urban residents from suburban residents and individuals with urban land use preferences from those with suburban land use preferences, and identified four groups: urban consonants, suburban consonants, urban dissonants, and suburban dissonants. The former two groups reside in the neighborhoods that are in congruence with their land use preferences whereas the latter two groups live in the neighborhoods that they do not prefer. Schwanen and Mokhtarian (2005a) further investigated the impact of residential dissonance on travel distance and found that dissonant urban residents traveled longer than consonant urbanites, but suburban consonants and suburban dissonants showed similar travel distance. Schwanen and Mokhtarian 
(2005b) compared mode choice among the four groups of people and concluded that the impact of residential dissonance was larger for suburban residents than for urban residents. Applying similar methods, De Vos et al. (2012) used 1,657 individuals in Flanders, Belgium, to evaluate the impact of residential dissonance on commute mode choice. They showed that residential dissonance influenced travel behavior of mismatched respondents, and that public transit use was mainly determined by preferences and only to a limited degree by the built environment.

Few studies have explored how residents' behavioral responses to rail transit/TOD vary by preferences. Cao (2015) explored the interaction effect of the Hiawatha LRT (in urban neighborhoods in South Minneapolis) and pro-transit attitude on transit commute frequency. $\mathrm{He}$ found that non-LRT consonants had the lowest frequency, followed by LRT dissonants, non-LRT dissonants, and then LRT consonants. Accordingly, although the effects of transit attitude and LRT are balanced in LRT neighborhoods, transit attitude plays a dominant role in suburban neighborhoods. Kamruzzaman et al. (2015) classified 2,675 commuters in Brisbane, Australia, into four groups: TOD consonants, TOD dissonants, non-TOD consonants, and non-TOD dissonants. They found that consonant non-TOD residents and dissonant TOD residents were more likely to use car and less likely to use public transport than dissonant non-TOD residents and consonant TOD residents. In a study of 3,957 individuals in Brisbane, Kamruzzaman et al. (2013) reached a similar conclusion: commuting mode choice is largely determined by travel attitudes than built environment factors.

This study attempts to fill the gaps by exploring the impact of metro transit on transit use in a fast-growing developing country and disentangling the effect of the propensity of living near rail transit. More importantly, it moves beyond the average treatment effect and explicitly considers interaction effects which researchers call for (Chatman, 2014).

\section{Methodology}

\subsection{Study area and research design}

Xi'an, located in the middle of the Guanzhong Plain, is the capital city of Shaanxi province and 
the political, economic and cultural centers of Northwestern China. Because Xi'an has more than 3,000-year history and was the capital for many dynasties in Chinese history, it is one of the most important cities in China. According to the 2010 Census, there were about 8.5 million permanent residents in Xi'an. It is the 10th Chinese city that introduced metro transit systems. It has an ambitious long-term plan of 17 metro transit routes of more than $600 \mathrm{~km}$ in length. Currently, Line 1 and Line 2 are in operation, and Line 3, Line 4, and Line 9 are under construction. The construction is under ground and hence has a limited disruption to surface transportation.

We compare residents living near metro transit stations and those away from stations to investigate the impact of metro transit on transit use. Because a random experiment is not feasible, this study employed a case-control observational design similar to Cao and Schoner (2014). It is ideal that case and control corridors have the same location context and built environment characteristics except for the presence of metro transit. In practice, there are no two same corridors in a region. In this study, we chose two parallel corridors. The case corridor is along Line 2, the first route in Xi'an. It was constructed in October 2006 and commenced in November 2011. The control corridor is along the forthcoming Line 4, which will start revenue service in 2017. Line 2 and the forthcoming Line 4 are two parallel routes running from north to south across Xi'an. The former is a $26.8 \mathrm{~km}$ line with 21 stations and the latter is a $35.2 \mathrm{~km}$ line with 29 stations. For each of the two lines, based on the characteristic of built environment, such as density, and the distances from the urban center and service facility, we selected urban and exurban neighborhoods ${ }^{1}$ around existing and future stations (Figure 1). Specifically, Beidajie of Line 2 and Dachaishi of the forthcoming Line 4 are urban stations. Sports Park of Line 2, Fengcheng Nine Road and Fenxin Road of the forthcoming Line 4 are exurban stations, which are located about $12 \mathrm{~km}$ away from the city center - the Bell Tower. We choose two exurban stations of the forthcoming Line 4 because there are fewer people living near Fengcheng Nine Road than Sports Park. We surveyed 59 residential complexes within 800 meters of these

\footnotetext{
1 We also selected suburban neighborhoods for each of the two lines. Because respondents in control neighborhoods are much more affluent than those in metro neighborhoods, we dropped the suburban neighborhoods for this analysis.
} 
stations.

[Insert Figure 1 here]

In both urban and exurban areas, there are no significant differences in the number of bus lines and road density (with 800 meters from the main entrance of residential complexes) between the residential complexes along Line 2 (called metro transit neighborhoods) and those along the forthcoming Line 4 (called control neighborhoods), as shown in Table 1. Although metro and control neighborhoods appear to be similar (Figure 2), metro transit neighborhoods have a significantly lower number of bus stops than control neighborhoods in both urban and exurban areas (Table 1). Population density of metro transit neighborhoods is higher than that of control neighborhoods in both urban and exurban areas. Therefore, it is important to control for built environment elements in the models for travel behavior.

[Insert Table 1here]

[Insert Figure 2 here]

As we expected, urban neighborhoods have significantly higher population density and better transit service than exurban neighborhoods, but the difference in road density is not significant. Figure 3 also shows significant differences in built environment characteristics. Different from the U.S., residential neighborhoods in China are generally mixed with shopping and service facilities. Most basic service facilities such as restaurants, grocery stores and banks are within walking distance of urban neighborhoods. However, there are much fewer facilities around exurban neighborhoods. Further, urban neighborhoods have a much better accessibility to malls and supermarkets than exurban neighborhoods.

\subsection{Data and variables}

The data came from a nine-page questionnaire administered in April - October, 2014. The survey was pretested by thirty residents living in those neighborhoods. Survey content was revised based on the feedback from pretesters. The survey was administered through structured 
face-to-face interviews. Specifically, we hired 25 undergraduate students from Shaanxi Normal University as interviewers. They received two-hour training before administering the survey. Respondents were recruited by knocking at the doors of residents and at open spaces and parks within the neighborhoods. Residential location was asked to make sure that respondents lived in our study areas. A small gift (less than 5 Yuan, equivalent to US\$ 0.8) was provided as an incentive for participation. The number of respondents totals 782. Although we did not keep an accurate record on the number of people who refused to participate, the response rate was estimated at $60-70 \%$ based on the feedback from interviewers.

Table 2 illustrates demographic characteristics of urban and exurban samples for different corridors. Residents living in metro transit neighborhoods have a higher level of education and household income than those in control neighborhoods in both urban and exurban areas. This makes sense because transit is still a key mode of transport and Chinese often pay a substantial housing premium for access to metro transit (Gu and Zheng, 2010; Pan and Zhang, 2008). Respondents in metro transit neighborhoods have a larger household and are younger than those in control neighborhoods in urban areas, but the opposite holds true in exurban areas. There is no significant difference in the percentage of women between metro transit and control neighborhoods in urban areas, but there is a smaller share of female respondents in metro transit neighborhoods than control neighborhoods in exurban areas. Because population data at the neighborhood level are unavailable in China, we cannot evaluate the representativeness of our sample. However, since our study focuses on explaining the relationships of other variables to transit use rather than on describing transit use per se, these differences are not expected to materially affect the results (Babbie, 1998; Crano et al., 2014).

[Insert Table 2 here]

The variables used in this study consist of five categories: travel behavior, residential preferences, travel attitudes, demographics, and built environment characteristics. Travel behavior variables include use of transit for commute and non-work purposes. Since weather conditions influence transit ridership (Arana et al., 2014; Böcker et al., 2015; Creemers et al., 2015), we adapted the 
question from previous studies (Cao, 2015; Cao et al., 2009b). Respondents were asked to indicate the number of days they used bus/rail to commute in a typical week with good weather, based on a six-point ordinal scale ranging from "Never", "Less than once per month", "1-3 times per month", "Once per week", "2-3 days per week", to "4-5 days per week". Similar to previous studies (Cao and Ettema, 2014; Cao and Schoner, 2013; Cao, 2015; Cao and Schoner, 2014), using the mean of each category and rounding into an integer, they were recoded as approximately "0", “1”, “2”, “4”, "11”, and "19” times per month, respectively. Respondents were also asked to answer the following question: "In a typical month with good weather, how often do you take public transit from your home to each of the following places for purposes other than work/school?" The seven non-work activities included going to civic building (ex., library), service provider (ex., bank, barber), shopping, going to restaurant or coffee place, entertainment, exercise, to pick up or drop off a passenger. The choice set contained "Never", "Less than once per month", "Once or twice per month", "about once every two weeks", "About once per week", and "Two or more times per week". Similarly, they were recoded as "0", "0.5", "1.5", "2.15", "4.3", and "12.9" times per month, respectively. The overall frequency for non-work trips is the summation of these seven frequencies and rounds up to an integer.

In terms of residential preferences, respondents were asked to indicate how important some characteristics were when they were looking for a place to live, on a four-point scale from "not at all important" (1) to "extremely important" (4). The questions are adapted from Cao et al. (2007). As shown in Figure 3, we conducted a confirmatory factor analysis for 22 characteristics and obtained six latent constructs for residential preferences: safety, transit, accessibility, attractiveness, walkability, and socializing.

[Insert Figure 3 here]

In the survey, respondents were asked to indicate the extent to which they agree or disagree with a number of statements about their attitudes toward daily travel, on a five-point scale from "Strongly disagree" (1) to "Strongly agree" (5). Using a confirmatory factor analysis (Figure 4), we obtained five travel attitude factors: safety of car, pro-transit, pro-drive, pro-bike, and 
pro-walk.

[Insert Figure 4 here]

The survey also contained a list of demographic characteristics which explain respondents' residential location choices. The demographics consist of gender, age, education, employment status, income, household structure, and so on.

Following the survey, we created a variety of built environment variables using ArcGIS 10.0. The variables include population density of neighborhoods, the number of transit stops, transit route-kilometers, road density, and intersections with 800 meters from the entrance of residential complexes, network distance to the closest transit stop, distance to the closest metro transit station, and distance to the city center.

\subsection{Propensity score}

This study is to test the interaction effect between metro transit and the propensity of living close to metro transit on transit use. When measuring the propensity, previous studies rely on one attitudinal variable, which is often derived from a factor analysis (Cho and Rodríguez, 2014). Although a factor score is a composite of several statements, it captures limited dimensions of residential preferences (Cao et al., 2009a). Many variables influence individuals' decision to live in neighborhoods with metro transit, so we need a scalar that integrates all of the variables. Propensity score (PS) is such a scalar (Rosenbaum and Rubin, 1983). In the literature, the PS has been used for matching subclassfication, and regression in the field of land use and travel behavior (Cao, 2010; Cao et al., 2010; Parady et al., 2014).

The rationale of using propensity score matching (PSM) is as follows. PSM was first introduced by Rosenbaum and Rubin (1983) and then has been widely used in evaluation studies. It a statistical method to estimate treatment effects of policies or other interventions by balancing the covariates that affect the assignment of the treatment (Li, 2011; Oakes and Johnson, 2006). In observational studies, the assignment of a treatment to research subjects is typically not random. 
Accordingly, subjects with the treatment are likely to differ systematically in some variables from those without the treatment. PSM attempts to reduce the bias resulting from these variables by matching treatment subjects and control subjects based on propensity score. The PS is the conditional probability that a subject receives the treatment given observed covariates X. It summarizes all the information of $\mathrm{X}$ that are relevant to the treatment assignment and reflects the propensity of a subject receiving the treatment.

In this research, residents were classified into two types: residents of neighborhoods with metro transit (treatment group) and residents of neighborhoods without metro transit (control group). The PS is defined as the conditional probability that an individual lives in metro transit neighborhoods given her/his observed characteristics. As described in Rosenbaum and Rubin (1985), we estimated a binary logit model to predict the PS, using demographic characteristics, residential preferences, and travel attitudes as independent variables.

\section{Results}

Table 3 presents the model for estimating the PS. Given the observed characteristics, about two thirds of respondents are correctly classified by the model. The PS reflects an individual's predisposition toward living in metro transit neighborhoods give her/his observed characteristics. A high score means a strong propensity for living in metro transit neighborhoods. To minimize multicollinearity between the interaction term (PS*Metro) and PS in the models presented later, we rescale the PS by subtracting 0.5 . Then the new PS ranges from -0.5 to 0.5 .

[Insert Table 3 here]

Because the dependent variables (transit trip frequency) in this study do not follow a normal distribution and their histograms have a long right hand tail, we need to transform them. We could choose a log-transformation or a Poisson family model. Since the dispersion factor, Alpha, is larger than zero (Table 4), the variance of transit trip frequency exceeds its mean. Accordingly, we adopt a negative binomial regression. We develop three models: Model 1 is for 
non-work travel frequency by transit (including both metro transit and bus); Model 2 is for commute frequency by metro transit, and Model 3 is for commute frequency by bus. To distinguish whether the differences in transit trip frequency are the effects of metro transit itself or built environment effects, we account for the influences of built environment elements in the models for transit trip frequency. Therefore, the models include a dummy variable called metro transit (indicating whether a respondent lives in metro transit neighborhoods), the PS (measuring the propensity of living in metro transit neighborhoods), a multiplicative interaction term between the PS and metro transit, and built environment variables. To obtain parsimonious models, the built environment variables that were insignificant at the 0.1 level are removed from the models.

[Insert Table 4 here]

Table 4 presents model results. To begin with, the number of bus stops within an 800-meter range of neighborhood entrance is positively associated with transit trip frequency in all three models. This makes sense because high accessibility to transit stops leads to frequent transit use. The negative sign of the urban dummy variable in Model 2 means that people live in an exurban neighborhood are more likely to use metro transit for commuting than urban residents. This is inconsistent with empirical findings in America and Europe. The discrepancy is because urban residents in China are more likely to walk for commuting. In this sample, exurbanites' average commute frequency by walking is 3.9 days per month, far below that of urban residents ( 6.3 days per month). The number of supermarkets within an 800-meter range of neighborhood entrance is negatively associated with non-work travel frequency by transit. Thus, if supermarkets are within walking distance, people are more likely to walk rather than take transit there.

After controlling for built environment variables, the interaction between the PS and metro transit has no significant effect on nonwork travel frequency by transit in Model 1. That is, residents' behavioral responses to the presence of metro transit do not vary according to their propensity of living in metro transit neighborhoods. Therefore, the interaction term is manually removed from the model. Overall, respondents who have a strong propensity to live in metro transit neighborhoods tend to use transit more frequently than those with a weak propensity. Transit trip 
frequency is also partly explained by metro transit. Since the coefficient for metro transit is 0.236, residents in metro transit neighborhoods use transit for nonwork travel about $27 \%$ $[=\exp (0.236)-1]$ more than those living away from metro transit. If we ignore the effects of built environment variables and the constant term, the relationships among nonwork travel frequency by transit, the PS, and metro transit can be approximately illustrated in Figure 5(a).

[Insert Figure 5 here]

In contrast, Model 2 shows that the interaction term between the PS and metro transit is significant. It is worth noting that once the interaction is significant, we cannot interpret the coefficients of the PS and metro transit as we did for Model 1 because their effects are conditional on each other. Figure 5(b) illustrates the relationships among commute frequency by metro transit, the PS, and metro transit. Similarly, the interaction term is significant in Model 3. As shown in Figure 5(c), when respondents' PS is within "-0.5 to 0.2 ", those living in metro transit neighborhoods appear to use bus for commute more often than those living away from metro transit. However, when respondents' PS exceeds 0.2, the latter seem to have a higher frequency than the former. The results in Models 2 and 3 indicate that the impacts of metro transit on commute frequency by metro and bus are conditional on the propensity of living in metro transit neighborhoods. When the PS is low, metro transit neighborhoods facilitate metro and bus commute. Once the PS reaches certain level, metro transit does not contribute much to metro and bus commute. Overall, the propensity has a larger impact on those living away from metro transit than those living in metro transit neighborhoods. Since affluent people tend to live in metro transit neighborhoods, the frequent use of bus for commute by those living away from metro transit may reflect the effect of economic constraints. It is worth noting that commute frequencies were measured as an ordinal scale. So we also developed ordered responses models. The outcomes (not shown) are consistent with the results presented here. Therefore, the recoding does not have a critical impact on the conclusions.

If we group the respondents into four categories as Schwanen and Mokhtarian (2004) and Kamruzzaman et al. (2015) did, we can illustrate the differences among the four groups of 
residents (Table 5 and Figure 5(d)). One-way ANOVA was used to identify significant differences among the four groups of residents. Least Significant Difference (LSD) comparison tests were used to further identify which categories are significantly different from other categories. As shown in Table 6, non-metro consonants commute by metro transit less frequently than the other three groups and there are no significant differences among the three groups. For bus commute frequency, non-metro consonants are also the lowest, followed by metro dissonants, non-metro dissonants, and metro consonants. There is no significant difference between the last two groups. These findings are consistent with (Cao, 2015; De Vos et al., 2012; Kamruzzaman et al. (2015)).

[Insert Table 5 here]

[Insert Table 6 here]

\section{Conclusions}

This study has sought to enhance our understanding of the complicated relationships among travel behavior, metro transit and land use characteristics, and attitudes toward land use and travel. Previous studies overwhelmingly focused on the average effect of rail transit on travel behavior. This research tests the interaction effect between metro transit and the propensity of living close to metro transit on transit use in Xi'an, China. It employs a case-control observational design to substantiate the hypothesis that travel behavior effect of rail transit varies based on individuals' preferences.

We find that the interaction term between metro transit and the propensity of living near metro transit significantly affects transit use for commuting although it is insignificant for nonwork trip frequency. The results clearly indicated that respondents with a strong propensity to live in metro transit neighborhoods tend to use transit more frequently than those with a weak propensity, and that metro transit seems to facilitate transit commute for the latter. Metro dissonants and non-metro consonants were less likely to use metro transit and bus to commute than metro consonants and non-metro dissonants. Moreover, non-metro dissonants and metro consonants 
have a similar frequency of using metro transit and bus to commute, again suggesting the important role of the propensity in affecting transit commute. If residents' propensity of living in metro transit neighborhoods is strong enough, they would use transit frequently no matter whether they live near metro transit. Overall, if we do not capture the influence of the interaction, we will misestimate the impacts of metro transit on transit use. Since using transportation policies to shape individuals' travel behavior is likely to produce different effects for different groups of people, planners should consider these differences so that they can accurately forecast travel demand for policy-making.

This study suggests a strong role of predisposition toward living in metro transit neighborhoods in shaping transit commute. Two barriers greatly hinder individuals' preference for metro transit and their transit use. With a limited number of routes, metro transit has yet to provide services for many employment centers. Accordingly, developing a metro transit network, increasing coverage areas, and improving job accessibility by metro transit are keys to nurture individuals' preference for metro transit. Further, during the peak hours, the crash load of metro transit lowers individuals' preference for metro transit. Therefore, reducing crowding and providing comfortable service are also important.

Since metro consonants use transit more frequently than metro dissonants, reducing mismatch in metro transit neighborhoods will help grow ridership. One way is to nurture existing residents' preference for metro transit by addressing the aforementioned barriers. Further, planners should create more opportunities for non-metro dissonants to move to metro transit neighborhoods and make them metro consonants. Because expensive housing around station areas prevents non-metro dissonants from realizing their preference, governments should encourage developers to offer affordable housing through land use policies such as mandates and density bonus.

Using propensity score to measure individuals' preference captures the influences of observed characteristics on residential location choice. However, it cannot address the effects of 
unobserved factors. Anyway, propensity score integrates the influences of various demographics and attitudes in this study. It represents a progress beyond the existing studies using only one attitudinal variable.

\section{References}

Adler, N. E., Boyce, T., Chesney, M. A., Cohen, S., Folkman, S., Kahn, R. L., and Syme, S. L. (1994). Socioeconomic status and health: the challenge of the gradient. American psychologist 49, 15.

Arana, P., Cabezudo, S., and Peñalba, M. (2014). Influence of weather conditions on transit ridership: A statistical study using data from Smartcards. Transportation research part A: policy and practice 59, 1-12.

Arrington, G., and Cervero, R. (2008). Effects of TOD on Housing, Parking, and Travel. In "Transit Cooperative Research Program,Transportation Research Board of the National Academies", Washington, DC

Böcker, L., Dijst, M., Faber, J., and Helbich, M. (2015). En-route weather and place valuations for different transport mode users. Journal of Transport Geography 47, 128-138.

Babbie, E. (1998). The Practice of Social Research 8th Edition (Wadsworth, Belmont, CA).

Bhat, C., and Guo, J. (2007). A comprehensive analysis of built environment characteristics on household residential choice and auto ownership levels. Transportation Research Part B: Methodological 41, 506-526.

Bhattacharjee, S., and Goetz, A. R. (2012). Impact of light rail on traffic congestion in Denver. Journal of Transport Geography 22, 262-270.

Cao, J., and Cao, X. (2014). The Impacts of LRT, Neighbourhood Characteristics, and Self-selection on Auto Ownership: Evidence from Minneapolis-St. Paul. Urban Studies 51, 2068-2087.

Cao, J., and Ettema, D. (2014). Satisfaction with travel and residential self-selection: How do preferences moderate the impact of the Hiawatha Light Rail Transit line? Journal of Transport and Land Use 7, 93-108.

Cao, J., and Schoner, J. (2013). Transportation Impact of Transitways: A Case Study of Hiawatha Light Rail Transit in Minneapolis.

Cao, X., Mokhtarian, P. L., and Handy, S. L. (2007). Cross-sectional and quasi-panel explorations of the connection between the built environment and auto ownership. Environment and Planning A 39, 830-847. 
Cao, X., Mokhtarian, P. L., and Handy, S. L. (2009a). Examining the Impacts of Residential Self-Selection on Travel Behaviour: A Focus on Empirical Findings. Transport Reviews 29, 359-395.

Cao, X. J. (2010). Exploring causal effects of neighborhood type on walking behavior using stratification on the propensity score. Environment and Planning A 42, 487-504.

Cao, X. J. (2015). Heterogeneous effects of neighborhood type on commute mode choice: An exploration of residential dissonance in the Twin Cities. Journal of Transport Geography 48, 188-196.

Cao, X. J., Mokhtarian, P. L., and Handy, S. L. (2009b). The relationship between the built environment and nonwork travel: A case study of Northern California. Transportation Research Part A: Policy and Practice 43, 548-559.

Cao, X. J., and Schoner, J. (2014). The influence of light rail transit on transit use: An exploration of station area residents along the Hiawatha line in Minneapolis. Transportation Research Part A: Policy and Practice 59, 134-143.

Cao, X. J., Xu, Z., and Fan, Y. (2010). Exploring the connections among residential location, self-selection, and driving: Propensity score matching with multiple treatments. Transportation research part A: policy and practice 44, 797-805.

Cervero, R. (1993). Ridership impacts of transit-focused development in California. University of California Transportation Center.

Cervero, R. (1994). Transit-based housing in California: evidence on ridership impacts. Transport Policy 1, 174-183.

Cervero, R. (2007). Transit oriented development's ridership bonus: a product of self-selection and public policies. Environment and Planning A 39, 2068-2085.

Cervero, R. (2013). Transit-Oriented Development transit-oriented development (TOD) and Land Use land use. In "Transportation Technologies for Sustainability", pp. 947-958. Springer.

Cervero, R., and Day, J. (2008). Suburbanization and transit-oriented development in China. Transport Policy 15, 315-323.

Chatman, D. G. (2013). Does TOD need the T? On the importance of factors other than rail access. Journal of the American Planning Association 79, 17-31.

Chatman, D. G. (2014). Estimating the effect of land use and transportation planning on travel patterns: Three problems in controlling for residential self-selection. Journal of Transport and Land Use 7, 47.

Cho, G.-H., and Rodríguez, D. A. (2014). The influence of residential dissonance on physical activity and walking: evidence from the Montgomery County, MD, and Twin Cities, MN, areas. Journal of Transport Geography 41, 259-267. 
Crano, W. D., Brewer, M. B., and Lac, A. (2014). "Principles and methods of social research," Routledge.

Creemers, L., Wets, G., and Cools, M. (2015). Meteorological variation in daily travel behaviour: evidence from revealed preference data from the Netherlands. Theoretical and Applied Climatology 120, 183-194.

De Vos, J., Derudder, B., Van Acker, V., and Witlox, F. (2012). Reducing car use: changing attitudes or relocating? The influence of residential dissonance on travel behavior. Journal of Transport Geography 22, 1-9.

Dittmar, H., and Ohland, G. (2004). "The new transit town: best practices in transit-oriented development," Island Press.

Garrett, T. A., and Castelazo, M. D. (2004). Light rail transit in America: Policy issues and prospects for economic development. Unpublished Manuscript, Federal Reserve Bank of St. Louis, Research Department.

Gu, Y., and Zheng, S. (2010). The Impacts of Rail Transit on Property Values and Land Development Intensity: The Case of No. 13 Line in Beijing [J]. Acta Geographica Sinica 2, 010 .

Guiliano, G. (2004). "Land Use Impacts of Transportation Investments-Highway and Transit."

Houston, D., Boarnet, M. G., Ferguson, G., and Spears, S. (2015). Can compact rail transit corridors transform the automobile city? Planning for more sustainable travel in Los Angeles. Urban Studies 52, 938-959.

Kamruzzaman, M., Baker, D., and Turrell, G. (2015). Do dissonants in transit oriented development adjust commuting travel behaviour? European Journal of Transport and Infrastructure Research 15, 66-77.

Kamruzzaman, M., Baker, D., Washington, S., and Turrell, G. (2013). Residential dissonance and mode choice. Journal of Transport Geography 33, 12-28.

Knowles, R. D. (1996). Transport impacts of Greater Manchester's Metrolink light rail system. Journal of Transport Geography 4, 1-14.

Krizek, K. (2000). Pretest-posttest strategy for researching neighborhood-scale urban form and travel behavior. Transportation Research Record: Journal of the Transportation Research Board 1722, 48-55.

Li, C.-L. (2011). Propensity Score Matching in Observational Studies with Multiple Time Points, The Ohio State University.

Lund, H. M., Cervero, R., and Wilson, R. W. (2004). "Travel characteristics of transit-oriented development in California," publisher not identified. 
Manaugh, K., and El-Geneidy, A. (2011). Validating walkability indices: How do different households respond to the walkability of their neighborhood? Transportation research part D: transport and environment 16, 309-315.

Naess, P. (2014). Tempest in a teapot: The exaggerated problem of transport-related residential self-selection as a source of error in empirical studies. Journal of transport and land use 7, 57-79.

Oakes, J. M., and Johnson, P. J. (2006). Propensity score matching for social epidemiology. Methods in social epidemiology 1, 370-393.

Pan, H., and Zhang, M. (2008). Rail transit impacts on land use: Evidence from Shanghai, China. Transportation Research Record: Journal of the Transportation Research Board, 16-25.

Parady, G., Takami, K., and Harata, N. (2014). Connection Between Built Environment and Travel Behavior: Propensity Score Approach Under a Continuous Treatment Regime. Transportation Research Record: Journal of the Transportation Research Board, 137-144.

Renne, J. L. (2005). "Transit-oriented development: measuring benefits, analyzing trends, and evaluating policy."

Rosenbaum, P. R., and Rubin, D. B. (1983). The central role of the propensity score in observational studies for causal effects. Biometrika 70, 41-55.

Rosenbaum, P. R., and Rubin, D. B. (1985). Constructing a control group using multivariate matched sampling methods that incorporate the propensity score. The American Statistician 39, 33-38.

Schwanen, T., and Mokhtarian, P. (2004). The extent and determinants of dissonance between actual and preferred residential neighborhood type. Environment and planning. B, planning and design $31,759-784$.

Schwanen, T., and Mokhtarian, P. (2005a). What if you live in the wrong neighborhood? The impact of residential neighborhood type dissonance on distance traveled. Transportation Research Part D: Transport and Environment 10, 127-151.

Schwanen, T., and Mokhtarian, P. L. (2005b). What affects commute mode choice: neighborhood physical structure or preferences toward neighborhoods? Journal of Transport Geography 13, 83-99.

Sharma, R., Newman, P., and Matan, A. (2015). Urban Rail-India's Great Opportunity for Sustainable Urban Development. In "European Transport Conference 2015".

Wang, R., and You, y. (2016). Review and prospect of urban subway construction. Technology outlook 5, 34 . 


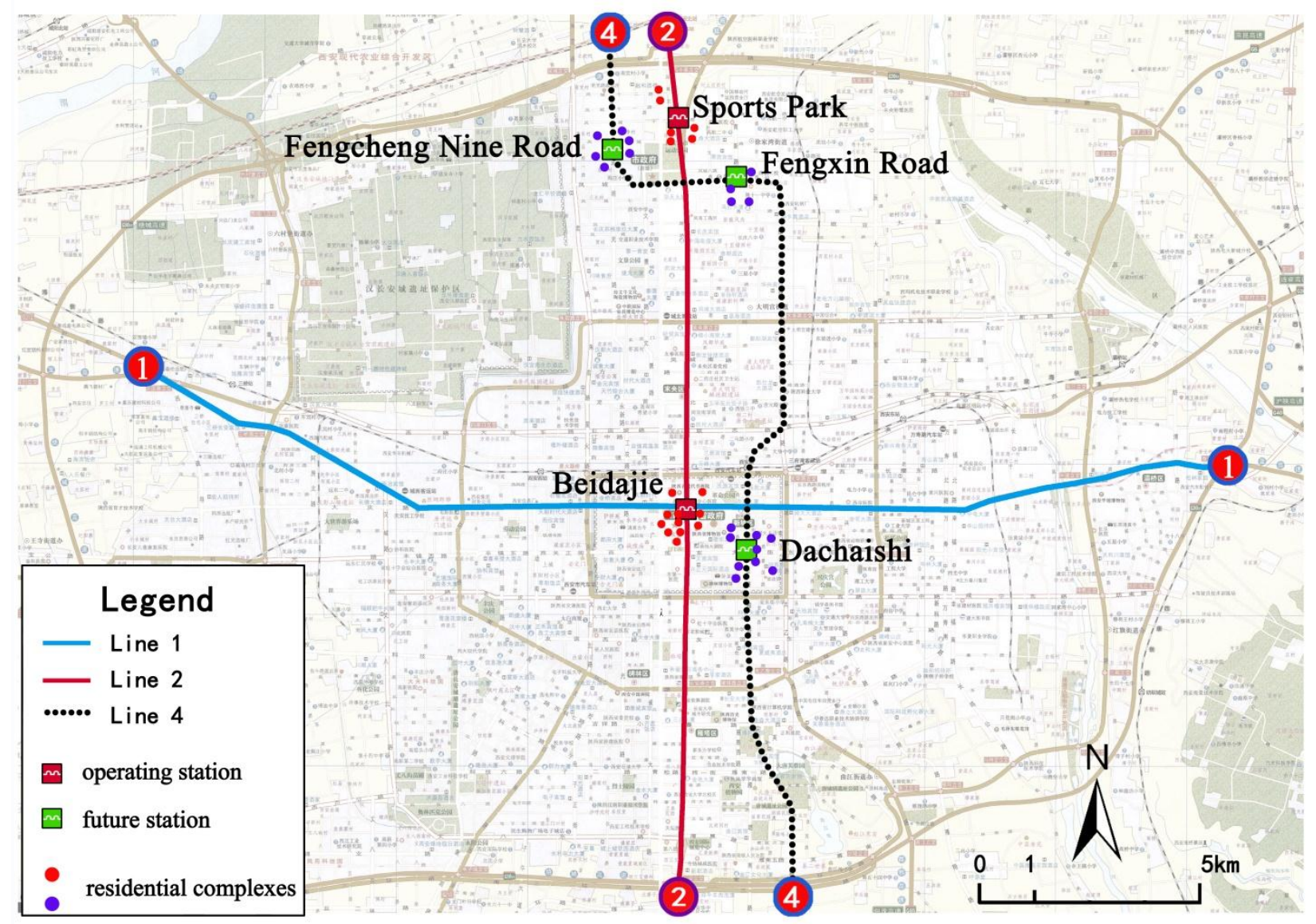

Figure 1. Location of sample residential complexes

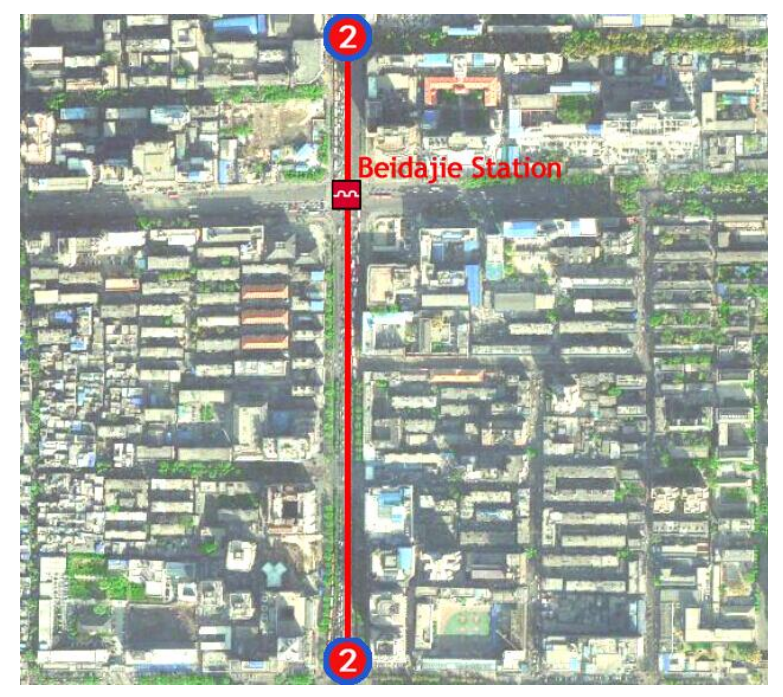






(a) Urban residential complexes along Line 2

(b) Urban residential complexes along the forthcoming Line 4
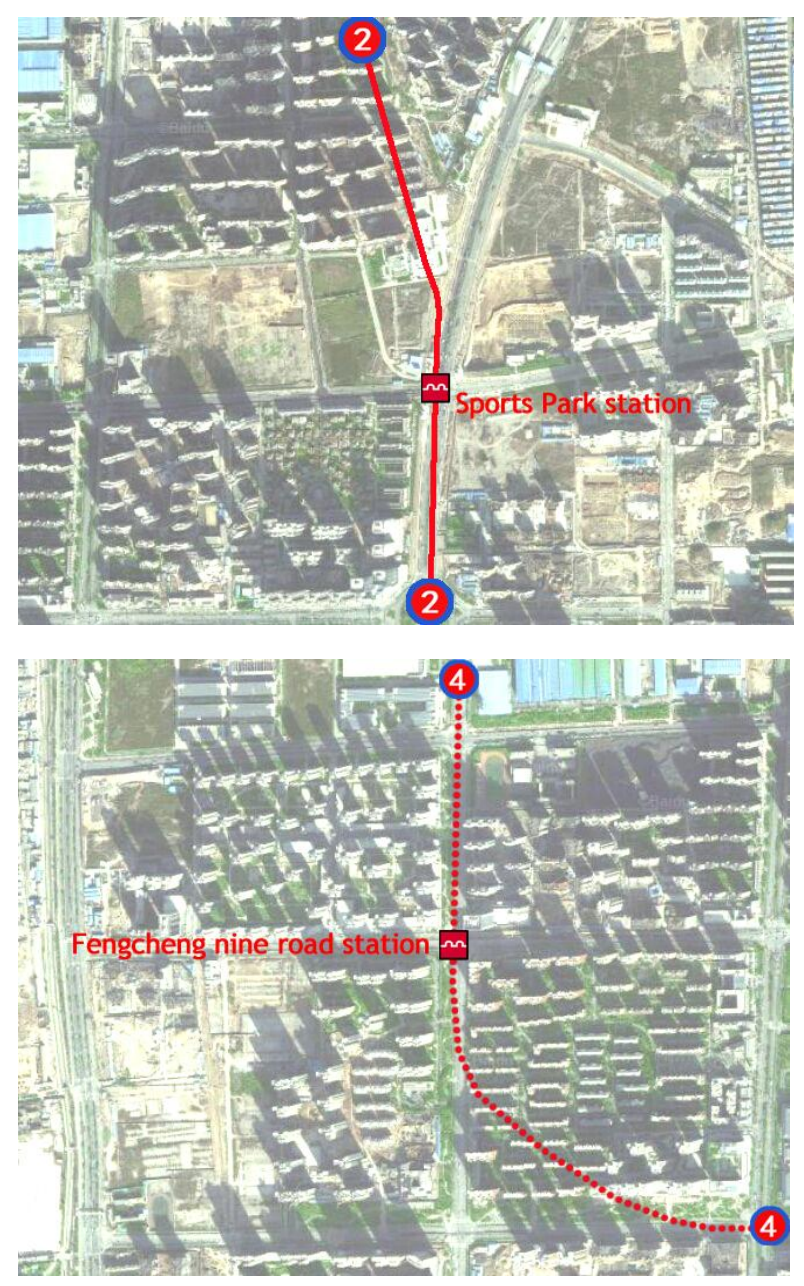

(c) Exurban residential complexes along Line 2

(d) Exurban residential complexes along the forthcoming Line 4 

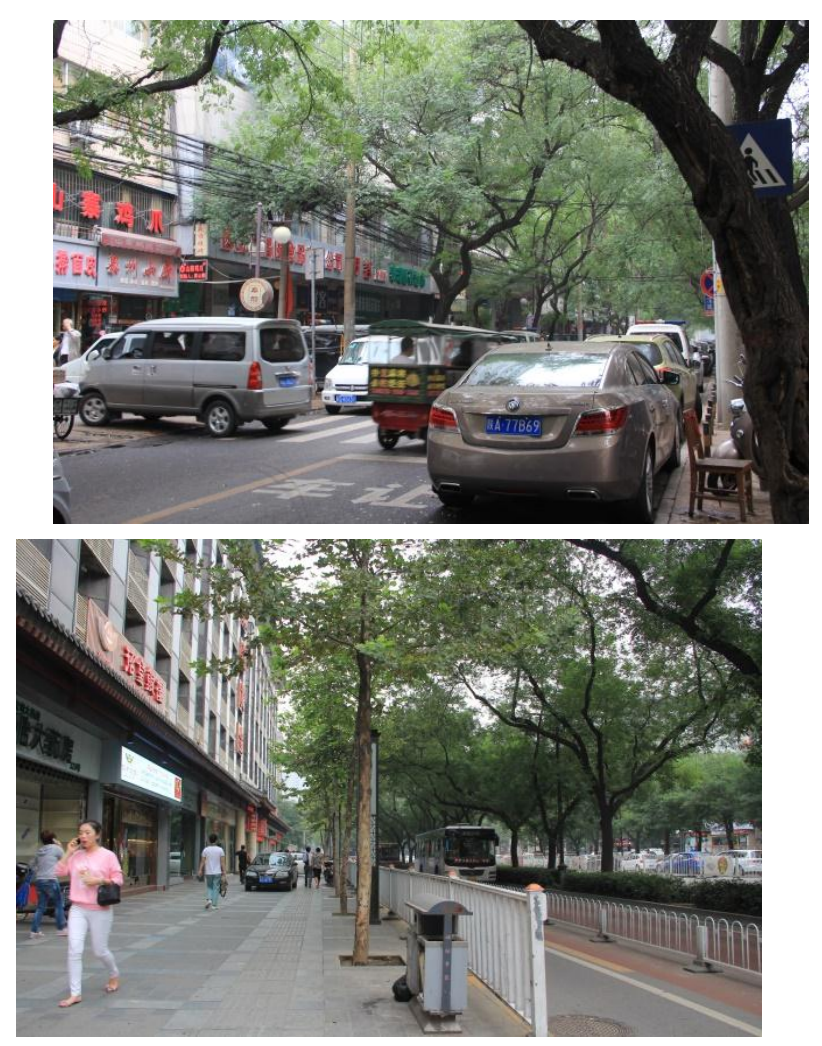

(e) Urban streets near Line 2

Urban streets near the forthcoming Line 4
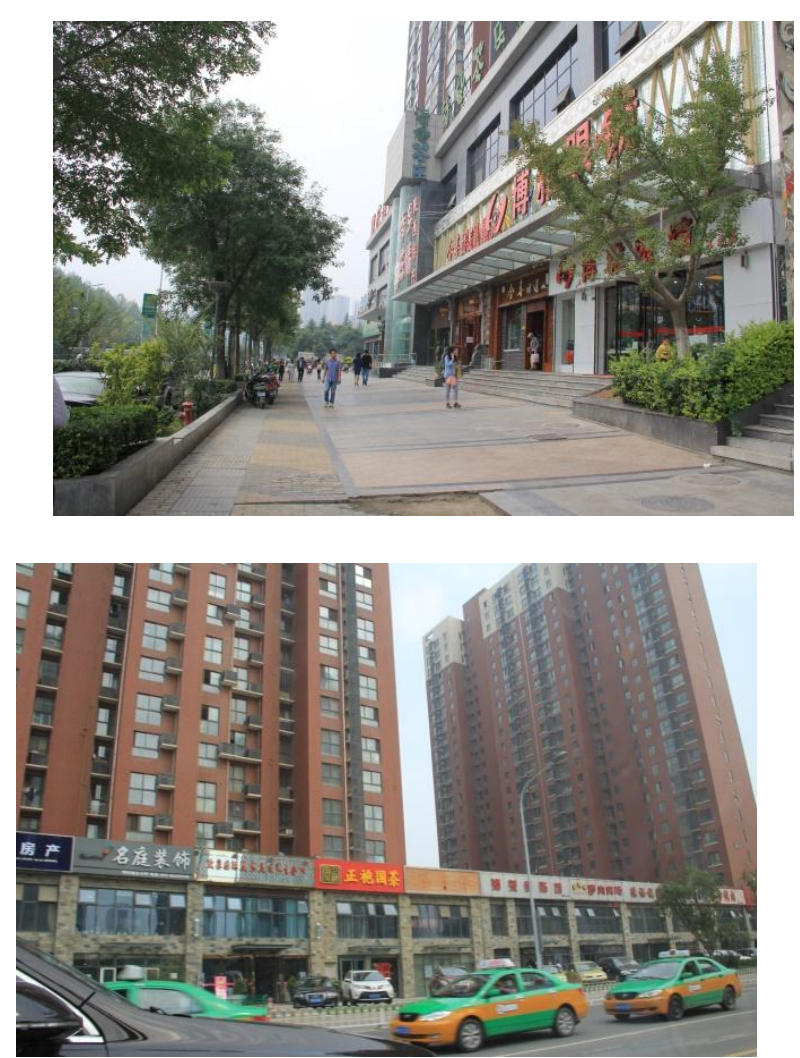
(g) Exurban streets near Line 2

(h) Exurban

streets near the forthcoming Line 4

Figure 2. Comparison of urban and exurban neighborhoods along Line 2 and the forthcoming Line 4 


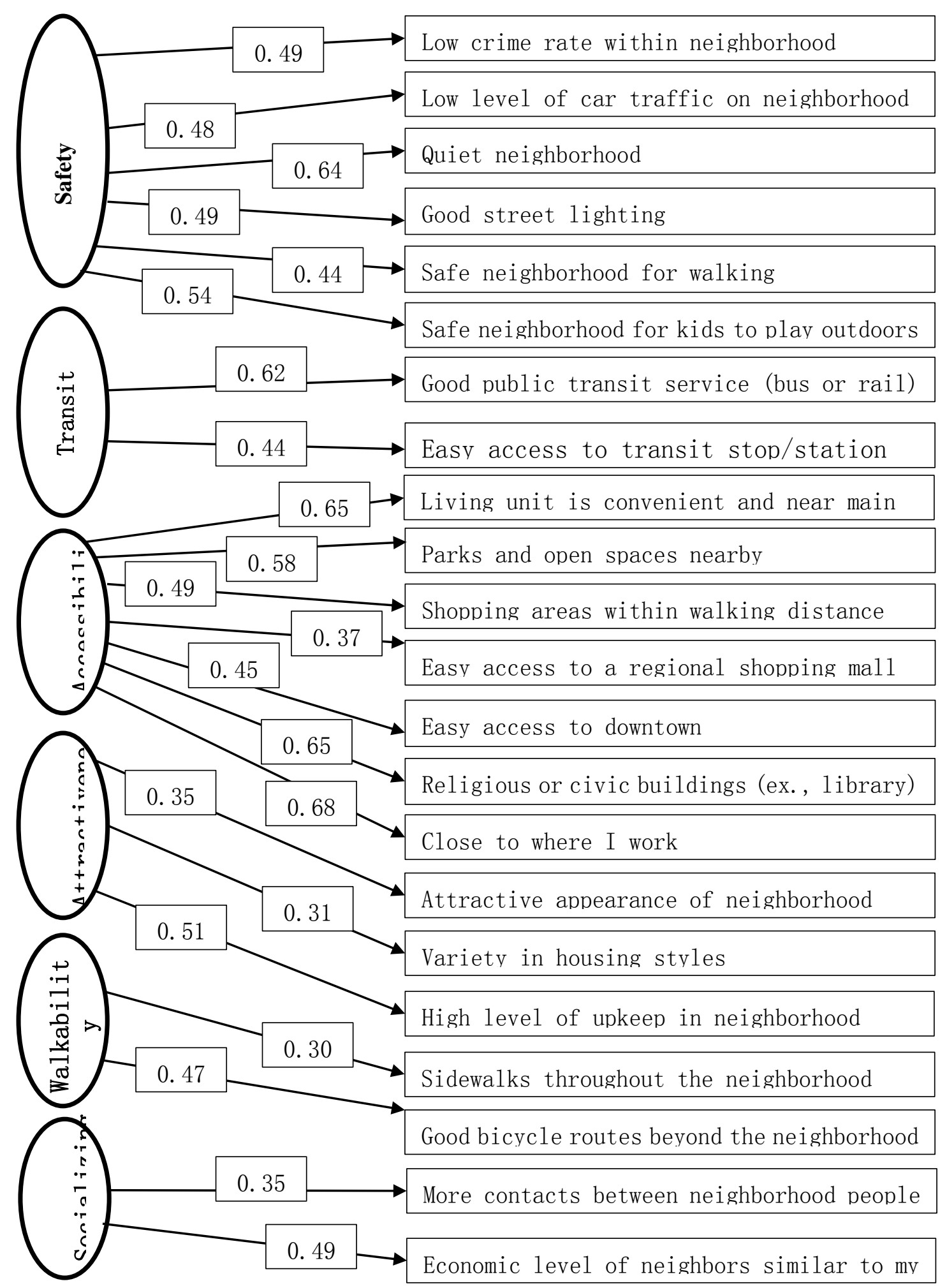

Notes:

The ellipses represent latent variables and the rectangles represent observed variables.

All coefficients are standardized and significant at the 0.01 level.

Goodness-of-fit measures: Root mean squared error of approximation $($ RMSEA $)=0.063<0.08$;

Standardized root mean squared residual $(\mathrm{SRMR})=0.052<0.08$; Comparative fit index $(\mathrm{CFI})=$ 0.875 .

Figure 3. Measurement models of residential preferences 


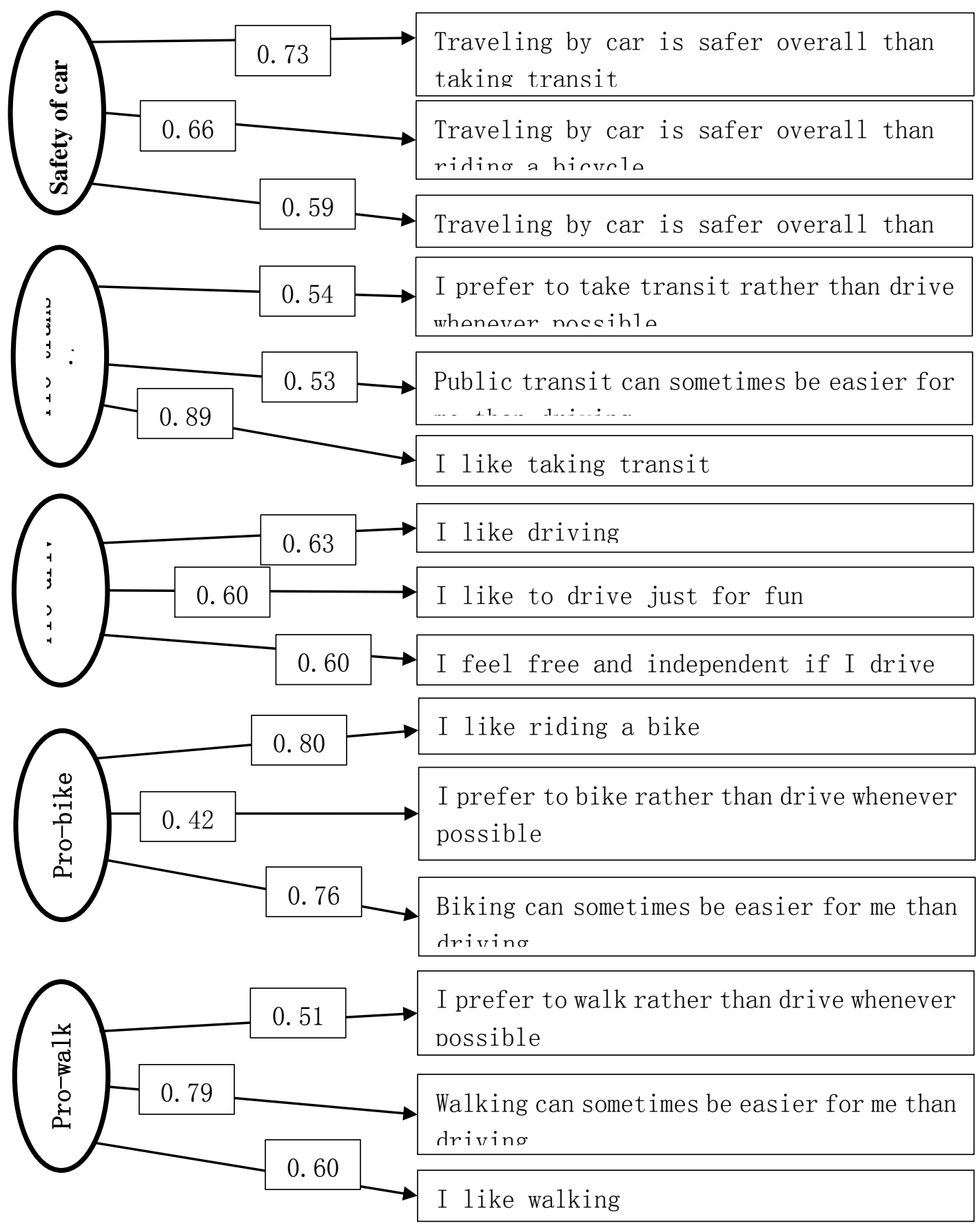

Notes:

The ellipses represent latent variables and the rectangles represent observed variables.

All coefficients are standardized and significant at the 0.01 level.

Goodness-of-fit measures: Root mean squared error of approximation (RMSEA) $=0.054<$ 0.08; Standardized root mean squared residual $(\mathrm{SRMR})=0.046<0.08$; Comparative fit index r igure 4. ivieasurement mouens or traven altumes 


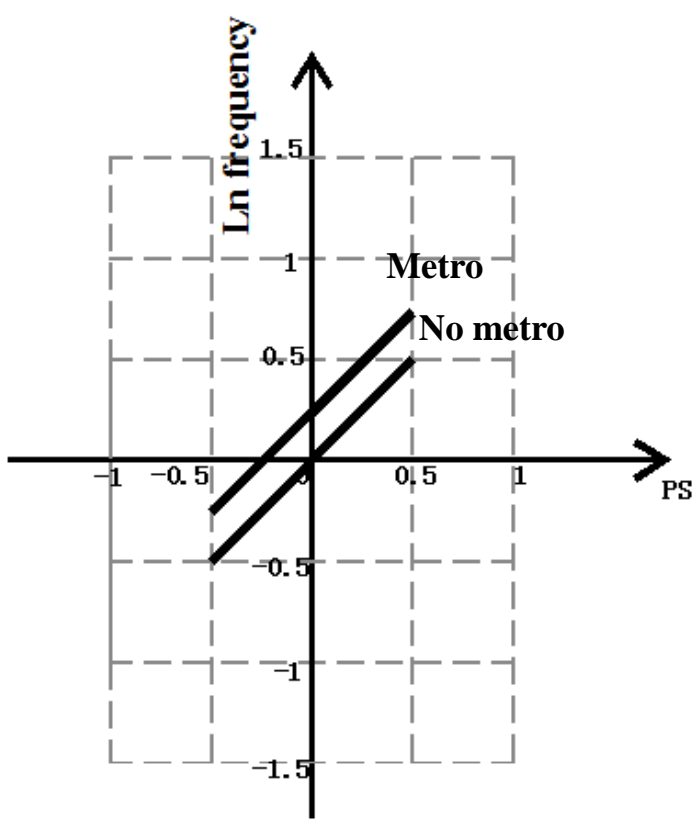

No metro

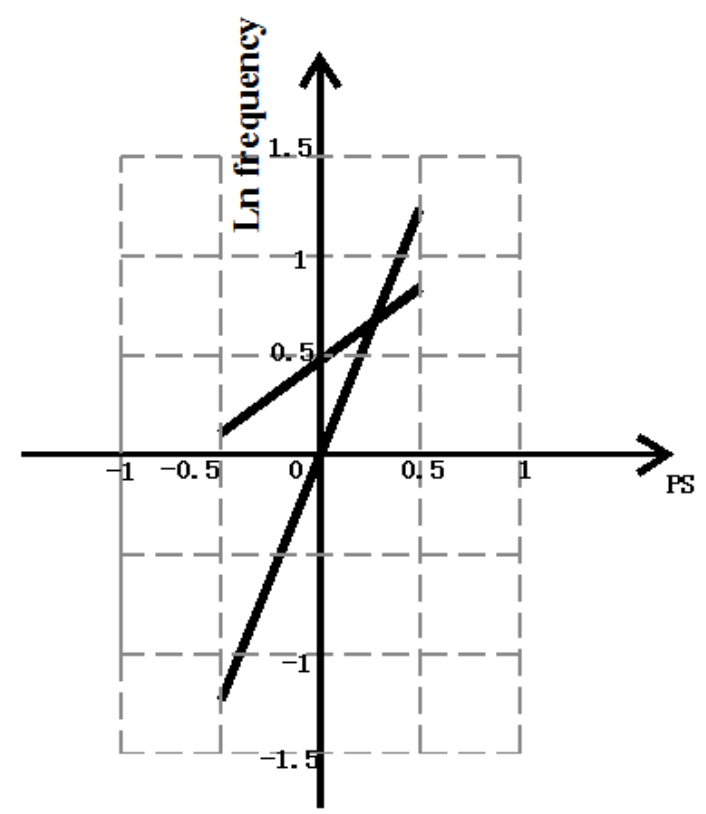

(a) Non-work travel by transit

(b) Commute by metro transit 

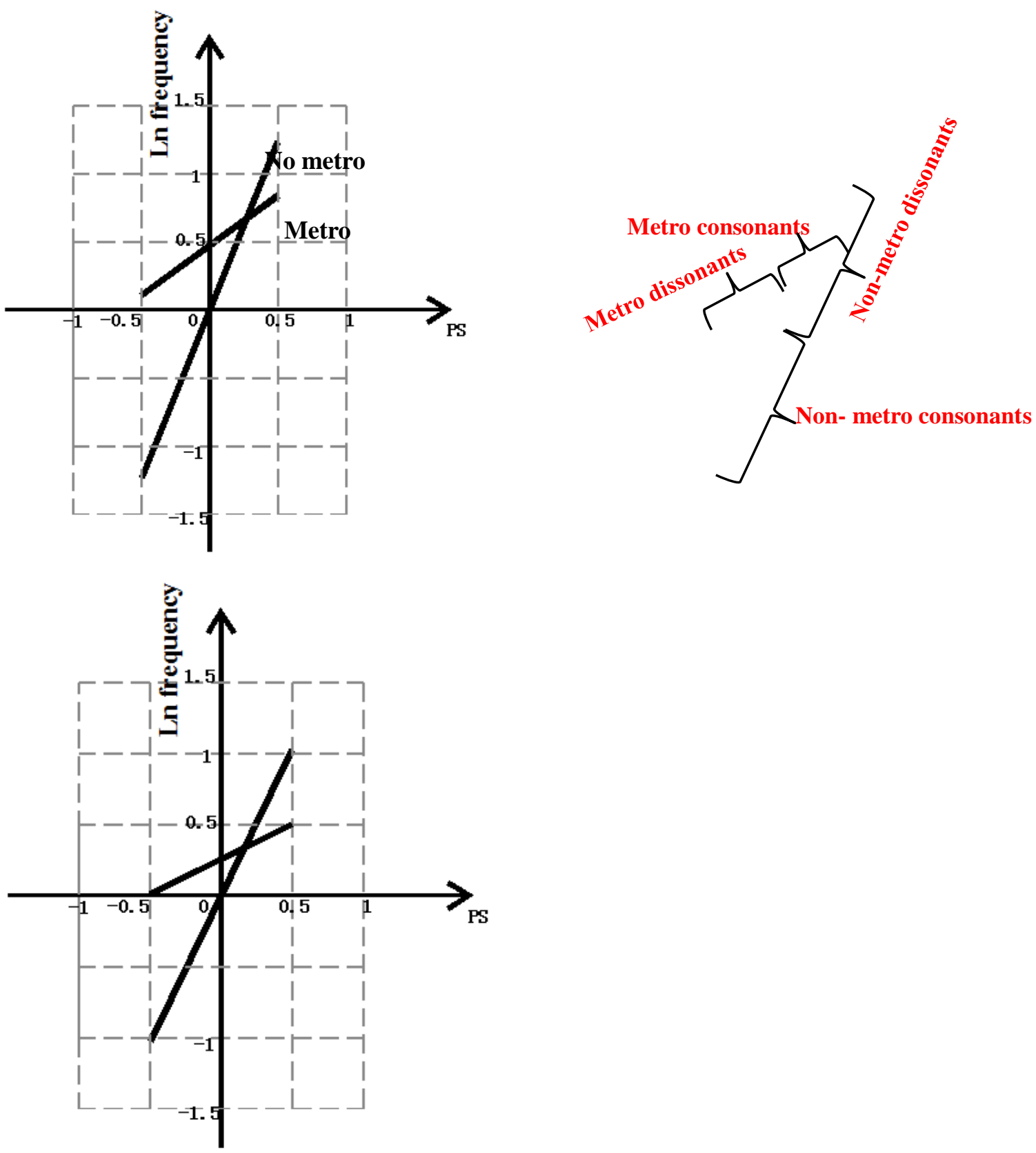

(c) Commute by bus

(d) Residential

dissonance and transit

Figure 5. The impacts of metro transit and propensity score on transit use 
Table 1. Built Environment Attributes of Urban and Exurban Residential Complexes along Line 2 and the Forthcoming Line 4.

\begin{tabular}{|c|c|c|c|c|c|}
\hline & $\begin{array}{c}\text { Mean } \\
\text { population } \\
\text { density of } \\
\text { neighborhoods } \\
\text { (person per } \\
\mathrm{km}^{2} \text { ) }\end{array}$ & $\begin{array}{c}\text { Mean } \\
\text { number } \\
\text { of bus } \\
\text { lines }\end{array}$ & $\begin{array}{c}\text { Mean } \\
\text { number of } \\
\text { bus stops }\end{array}$ & $\begin{array}{c}\text { Mean } \\
\text { road } \\
\text { density } \\
\left(\mathrm{km} / \mathrm{km}^{2}\right)\end{array}$ & $\begin{array}{l}\text { Number of } \\
\text { residential } \\
\text { complexes }\end{array}$ \\
\hline Exurban & 6778.00 & 15.40 & 6.66 & 4.75 & 29 \\
\hline Line4(Control) & 5259.25 & 15.60 & 8.23 & 4.78 & 12 \\
\hline Line2(Metro transit) & 8193.04 & 15.21 & 5.21 & 4.73 & 17 \\
\hline P-value (Line4 and Line2) & 0.00 & 0.53 & 0.00 & 0.73 & - \\
\hline Urban & 24816.65 & 47.67 & 12.64 & 8.97 & 30 \\
\hline Line4(Control) & 21681.84 & 54.81 & 13.12 & 9.89 & 21 \\
\hline Line2(Metro transit) & 27951.47 & 40.53 & 12.17 & 8.05 & 9 \\
\hline P-value (Line4 and Line2) & 0.00 & 0.55 & 0.00 & 0.95 & - \\
\hline $\begin{array}{r}\text { P-value (urban and exur } \\
\text { ban) }\end{array}$ & 0.00 & 0.00 & 0.00 & 0.26 & - \\
\hline
\end{tabular}

Table 2.Sample Demographic Characteristics for Different Corridors

\begin{tabular}{|c|c|c|c|c|c|c|}
\hline & $\%$ female & $\begin{array}{l}\text { Mean } \\
\text { age }\end{array}$ & $\begin{array}{c}\text { Mean } \\
\text { educatio } \\
n\end{array}$ & $\begin{array}{c}\text { Mean } \\
\text { househol } \\
\text { d size }\end{array}$ & $\begin{array}{l}\text { Mean } \\
\text { income }\end{array}$ & $\begin{array}{l}\text { Number } \\
\text { of } \\
\text { sample } \\
\text { residents }\end{array}$ \\
\hline Exurban & 49 & 38.69 & 4.00 & 3.87 & 3.23 & 396 \\
\hline Line4(Control) & 56 & 42.37 & 3.71 & 3.90 & 2.96 & 191 \\
\hline Line2(Metro transit) & 43 & 35.26 & 4.27 & 3.84 & 3.49 & 205 \\
\hline P-value (Line4 and Line2) & 1 & 0.00 & 0.00 & 0.72 & 0.00 & - \\
\hline Urban & 51 & 41.65 & 3.98 & 3.70 & 2.58 & 386 \\
\hline Line4(Control) & 52 & 44.79 & 3.79 & 3.39 & 2.27 & 193 \\
\hline Line2(Metro transit) & 53 & 38.50 & 4.16 & 4.01 & 2.88 & 193 \\
\hline P-value (Line4 and Line2) & 84 & 0.00 & 0.00 & 0.00 & 0.00 & - \\
\hline $\begin{array}{r}\text { P-value (urban and exur } \\
\text { ban) }\end{array}$ & 35 & 0.01 & 0.96 & 0.10 & 0.00 & 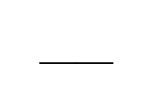 \\
\hline
\end{tabular}


Table 3. Propensity Score Model for Living in Metro Transit neighborhoods

\begin{tabular}{|c|c|c|c|c|}
\hline & Factor & Coeff. & z-statistic & P-value \\
\hline \multirow{8}{*}{ Demographics } & Constant & -1.464 & -2.66 & 0.008 \\
\hline & Age & -0.022 & -3.73 & 0.000 \\
\hline & Male & 0.386 & 2.42 & 0.015 \\
\hline & Education & 0.222 & 2.53 & 0.011 \\
\hline & License & -0.364 & -1.85 & 0.064 \\
\hline & Number of drivers & -0.005 & -0.05 & 0.958 \\
\hline & Income & 0.331 & 4.74 & 0.000 \\
\hline & Household size & 0.122 & 2.21 & 0.027 \\
\hline \multirow{5}{*}{$\begin{array}{c}\text { Travel } \\
\text { attitudes }\end{array}$} & Pro-transit & -0.613 & -1.16 & 0.247 \\
\hline & Pro-drive & 0.079 & 0.40 & 0.686 \\
\hline & Pro-bike & 0.181 & 0.96 & 0.336 \\
\hline & Pro-walk & 0.284 & 1.07 & 0.283 \\
\hline & safety of car & -0.385 & -1.81 & 0.070 \\
\hline \multirow{6}{*}{$\begin{array}{l}\text { Residential } \\
\text { preferences }\end{array}$} & Safety & 0.545 & 2.02 & 0.044 \\
\hline & Transit & 0.242 & 0.59 & 0.553 \\
\hline & Accessibility & -0.083 & -0.17 & 0.869 \\
\hline & Attractiveness & -0.190 & -1.30 & 0.193 \\
\hline & Walkability & -0.143 & -0.72 & 0.474 \\
\hline & Socializing & -0.239 & -1.68 & 0.092 \\
\hline \multicolumn{2}{|c|}{ Log likelihood at 0} & & -542.0 & \\
\hline \multicolumn{2}{|c|}{ Log likelihood at convergence } & & -491.3 & \\
\hline \multicolumn{2}{|l|}{ McFadden $\mathrm{R}^{2}$} & & 0.094 & \\
\hline \multicolumn{2}{|c|}{ Number of observations } & & 782 & \\
\hline
\end{tabular}


Table 4. Negative Binomial Models for Transit Trip Frequency

\begin{tabular}{|c|c|c|c|c|c|c|}
\hline \multirow[b]{3}{*}{ Variables } & \multirow{2}{*}{\multicolumn{2}{|c|}{$\begin{array}{c}\text { Model } 1 \\
\text { Non-work travel by } \\
\text { transit }\end{array}$}} & \multicolumn{2}{|c|}{ Model 2} & \multicolumn{2}{|c|}{ Model 3} \\
\hline & & & \multicolumn{2}{|c|}{$\begin{array}{c}\text { Commute by metro } \\
\text { transit }\end{array}$} & \multicolumn{2}{|c|}{ Commute by Bus } \\
\hline & Coeff. & P-value & Coeff. & P-value & Coeff. & P-value \\
\hline $\mathrm{PS} * \mathrm{M}$ & & Insig. & -1.730 & 0.024 & -1.563 & 0.022 \\
\hline Propensity Score (PS) & 0.992 & 0.000 & 2.463 & 0.000 & 2.052 & 0.000 \\
\hline Metro transit (M) & 0.236 & 0.013 & 0.476 & 0.001 & 0.255 & 0.028 \\
\hline Number of bus stops & 0.068 & 0.000 & 0.061 & 0.007 & 0.041 & 0.002 \\
\hline Urban & & Insig. & -0.750 & 0.000 & & Insig. \\
\hline Number of supermarkets & -0.014 & 0.000 & & Insig. & & Insig. \\
\hline Constant & 1.560 & 0.000 & 0.854 & 0.210 & 1.349 & 0.000 \\
\hline Dispersion parameter $\alpha$ & \multicolumn{2}{|c|}{1.059} & \multicolumn{2}{|c|}{2.300} & \multicolumn{2}{|c|}{1.932} \\
\hline Number of observations & \multicolumn{2}{|c|}{770} & \multicolumn{2}{|c|}{770} & \multicolumn{2}{|c|}{770} \\
\hline
\end{tabular}

Table 5. Defining Four Groups of Residents

\begin{tabular}{|c|c|c|c|}
\hline & $\begin{array}{l}\text { Whether living in } \\
\text { metro transit } \\
\text { neighborhoods }\end{array}$ & \multicolumn{2}{|c|}{$\begin{array}{l}\text { The propensity score of living in metro } \\
\text { transit neighborhoods }\end{array}$} \\
\hline Metro consonants & metro residents & $0.5-1$ & $\begin{array}{l}\text { with a preference for living in a } \\
\text { neighborhood with transit }\end{array}$ \\
\hline Metro dissonants & metro residents & $-0.5-0$ & $\begin{array}{l}\text { with a preference for living in a } \\
\text { neighborhood with metro transit }\end{array}$ \\
\hline $\begin{array}{l}\text { Non- } \\
\text { consonants }\end{array}$ & non-metro residents & $-0.5-0$ & $\begin{array}{l}\text { with a preference for living in a } \\
\text { neighborhood with metro transit }\end{array}$ \\
\hline $\begin{array}{l}\text { Non-metro } \\
\text { dissonants }\end{array}$ & non-metro residents & $0.5-1$ & $\begin{array}{l}\text { with a preference for living in a } \\
\text { neighborhood with transit }\end{array}$ \\
\hline
\end{tabular}


Table 6. One-way ANOVA for Transit Trip Frequency of Four Groups of Residents

\begin{tabular}{|c|c|c|c|c|c|c|c|}
\hline & $\begin{array}{l}\text { Metro } \\
\text { transit } \\
\text { commute }\end{array}$ & $\begin{array}{l}\text { Bus } \\
\text { commute }\end{array}$ & & \multicolumn{2}{|c|}{$\begin{array}{l}\text { Metro transit } \\
\text { commute }\end{array}$} & \multicolumn{2}{|c|}{ Bus commute } \\
\hline I & $\begin{array}{c}\text { Mean } \\
\text { frequency }\end{array}$ & $\begin{array}{c}\text { Mean } \\
\text { frequency }\end{array}$ & $\mathrm{J}$ & $\begin{array}{c}\text { Differe } \\
\text { nce } \\
(\mathrm{I}-\mathrm{J})\end{array}$ & $\begin{array}{c}\text { LSD } \\
\text { P-value }\end{array}$ & $\begin{array}{c}\text { Differe } \\
\text { nce } \\
(\mathrm{I}-\mathrm{J})\end{array}$ & $\begin{array}{c}\text { LSD } \\
\text { P-valu } \\
\text { e }\end{array}$ \\
\hline \multirow{3}{*}{$\begin{array}{c}\text { Metro } \\
\text { consonants }\end{array}$} & \multirow{3}{*}{5.00} & \multirow{3}{*}{7.77} & Metro dissonants & 0.84 & 0.168 & 1.51 & 0.054 \\
\hline & & & $\begin{array}{l}\text { Non-metro } \\
\text { consonants }\end{array}$ & 2.95 & 0.000 & 3.24 & 0.000 \\
\hline & & & $\begin{array}{l}\text { Non-metro } \\
\text { dissonants }\end{array}$ & -0.12 & 0.834 & 0.22 & 0.765 \\
\hline \multirow{3}{*}{$\begin{array}{l}\text { Non-metro } \\
\text { dissonants }\end{array}$} & \multirow{3}{*}{5.12} & \multirow{3}{*}{7.55} & Metro dissonants & 0.96 & 0.161 & 1.29 & 0.144 \\
\hline & & & Metro consonants & 0.12 & 0.834 & -0.22 & 0.765 \\
\hline & & & $\begin{array}{l}\text { Non-metro } \\
\text { consonants }\end{array}$ & 3.07 & 0.000 & 3.02 & 0.000 \\
\hline \multirow{3}{*}{$\begin{array}{c}\text { Metro } \\
\text { dissonants }\end{array}$} & \multirow{3}{*}{4.16} & \multirow{3}{*}{6.26} & Metro consonants & -0.84 & 0.168 & -1.51 & 0.054 \\
\hline & & & $\begin{array}{l}\text { Non-metro } \\
\text { consonants }\end{array}$ & 2.11 & 0.001 & 1.73 & 0.031 \\
\hline & & & $\begin{array}{l}\text { Non-metro } \\
\text { dissonants }\end{array}$ & -0.96 & 0.161 & -1.29 & 0.144 \\
\hline \multirow{3}{*}{$\begin{array}{l}\text { Non-metro } \\
\text { consonants }\end{array}$} & \multirow{3}{*}{4.00} & \multirow{3}{*}{4.53} & Metro dissonants & -2.11 & 0.001 & -1.73 & 0.031 \\
\hline & & & Metro consonants & -2.95 & 0.000 & -3.24 & 0.000 \\
\hline & & & $\begin{array}{l}\text { Non-metro } \\
\text { dissonants }\end{array}$ & -3.07 & 0.000 & -3.02 & 0.000 \\
\hline ANOVA & 0.000 & 0.00 & & & & & \\
\hline P-value & & 0 & & & & & \\
\hline
\end{tabular}

